戸塚山古墳出土女性人骨の拡大した顎関節と歯の異常磨耗

\author{
馬場悠男・茂原信生・芹沢雅夫・江藤盛治 \\ 独協医科大学第一解剖学教室
}

\begin{abstract}
要約 米沢市戸塚山古墳出土女性人骨に䫣関節の変化之歯の異常磨耗が見られた。
下顎窩は後下方に拡大し，下顎頭にもそれに対応する関節面が形成されている。左下顎歯

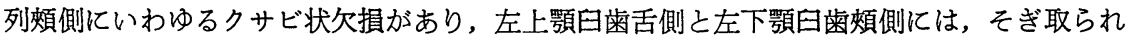
たような異常磨耗がある。乙の斜めの異常磨耗は細い棒等を挡入することによって形成され たと推測される。
\end{abstract}

はじめ に

1982年 5 月に米沢市教育委員会によって戸塚山第 137号古墳が発掘され，その際に人骨一体分が発見さ れた。この人骨はやや小柄な, 壮年中後期の女性のも のと考えられる。人骨の詳細は調査報告書の一部とし て出版されるが (馬場他，1983)，本稿では，ての人 骨に見られた特異な顎関節と歯の磨耗につき報告し， 若干の考察を加える。写真は当教室の阿部修二君のお 世話になった。

所見

\section{顎関節}

頭蓋右半の大部分は失われており，右下顎窩は残っ ていない(Plate I-1)。しかし，右下顎枝上部の保存 は良好であり，右靧関節の状態を推測するととができ る(Plate I-5)。

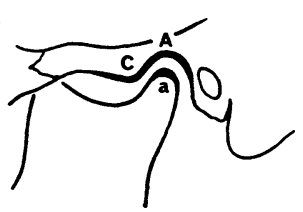

1

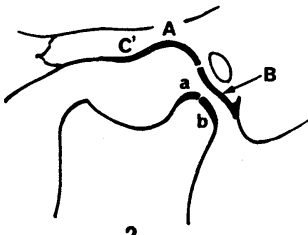

2
Fig.I. Diagram for comparison of temporomandibular joints in normal (1) and Tozukayama (2) specimens. Left lateral view. The articular disk is omitted. A : mandibular fossa, B: extended articular surface, C: articular tubercle, $C^{\prime}$ : very low articular tubercle in Tozukayama specimen, a: articular surface on the mandibular condyle, b: extended articular surface (contacts with $B$ ).

論文番号 8304
左側の下顎窩 (Fig. I-A) は後下方に大きく広が り，通常には見られない関節面を形成している(Plate I-3 矢印, Fig. I-B)。乙のために骨性外耳道を形成 する鼓室部は肥厚し, 後下方及び外方にも拡大してい る。なお，前方の関節結節は発達していない(Fig. I-C')。

これらの関節面と接する左下顎頭関節面 (Fig. I-a) は, その外側部がやや退縮し, そのかわり後面に, 連 続しているが，明瞭に区別しうるもう一つの関節面を 持っている(Plate I-4 矢印, Fig. I-b)。右下顎頭 も左側とほぼ同様の形態である (Plate I-5)。

なお，関節円板がどのような状態であったかは不明 である。

歯の概略

この個体の歯の保存状態および一般的特徽を以下に まとめた（Plate II-1-5)。

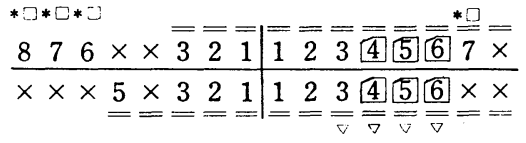

$$
\begin{aligned}
& =\text {, : 㐘槽の残っている部分, } \times \text { : 欠損また } \\
& \text { は紛失, *: 歯冠部の著しい歯石沈着, : : } \\
& \text { セメント質の著しい肥大, } \square \text { : 斜めの異常磨 } \\
& \text { 耗, } \nabla \text { : クサビ状欠損。 }
\end{aligned}
$$

歯冠咬合面の通常磨耗は Molnar の 2 3 度であ る。また, 上顎切歯舌側面と下顎切歯唇側面には釷状 咬合特有の咬耗が見られる。右上頼第 $1,2,3$ 大日 歯および左上顎第 2 大曰歯の歯冠には歯石の沈着が見 られ，歯根のセメント質肥大す著しいので，対向する 下顎歯はかなり早期に抜けていたと考えられる(Plate II-1-5)。 
斜めの異常磨耗

左上下顎の第 1 小曰歯から第 1 大曰歯にかけて，通 常には見られない異常な磨耗がある。すなわち，上顎 歯の舌側と下顎歯の煩側に，斜めにそぎ取られたよう な磨耗面が見られる (Plate II-6,Figs. II, III-B)。 特に上顎第 1 大日歯之下顎の第 2 小曰歯および第 1 大 日歯では, 歯冠の半分ほどが失われ, 磨耗はさらに歯 頸部まで及んでいる。しかし，歯䯣腔は露出せず，第
2 象牙質によって埋められている。なお, 左下額第 1 大曰歯のこの斜めの磨耗面には，かなり大きい破損部 が見られる (Fig. II)。また，乙の磨耗面とは別に， 咬合によらない狭い磨耗面と小さな破損部が歯冠上部 に点在している。

\section{クサビ状欠損}

下顎左側の犬歯から第 1 大田歯の煩側歯頸部には,

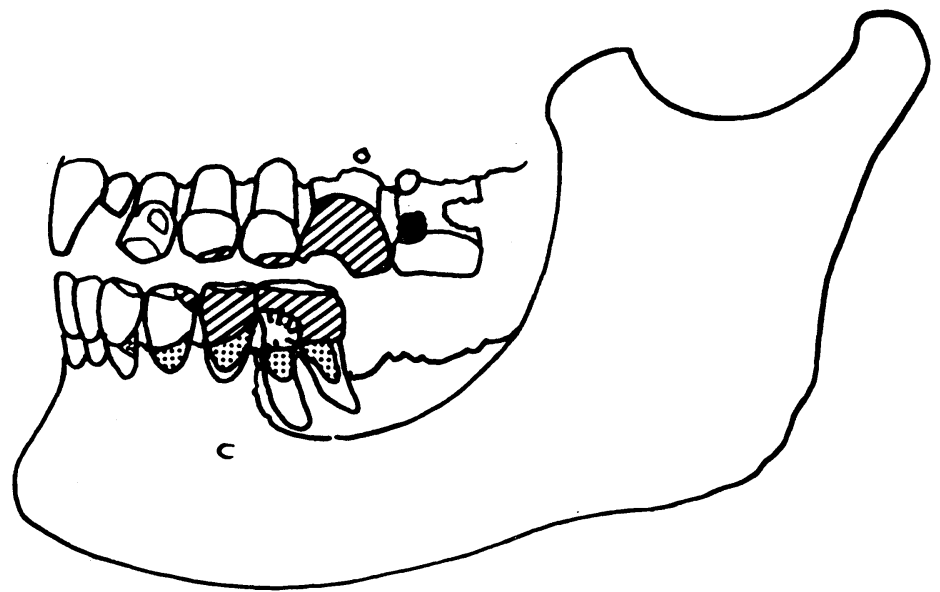

Fig. II. Dental attrition in Tozukayama Specimen (left lateral view). The attritions in the lingual side of the upper cheek teeth were projected to the buccal side. Striated areas indicate oblique attritions and dotted areas indicate so-called wedge-shaped defect. See Fig. III.

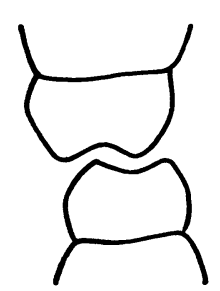

1

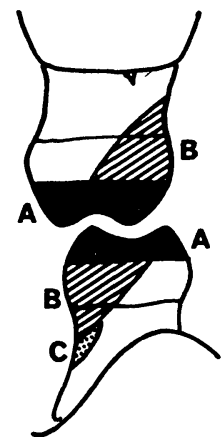

2

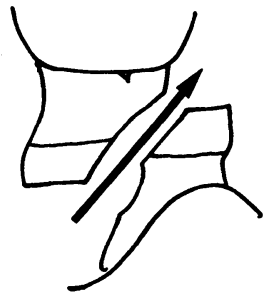

3

Fig. III. Diagram for the dental attrition in Tozukayama Specimen. 1: normal occlusion of cheek teeth, 2: attrition in Tozukayama, A: ordinal attrition, B: oblique attrition on the lingual side of the upper teeth and on the buccal side of the lower teeth, $\mathrm{C}$ : so-called wedge-shaped defect on the buccal side of the neck of the teeth, 3: final shape and occlusion of the cheek teeth in Tozukayama. An arrow shows the insertion of the chopstick-like object which caused the oblique attrition. 


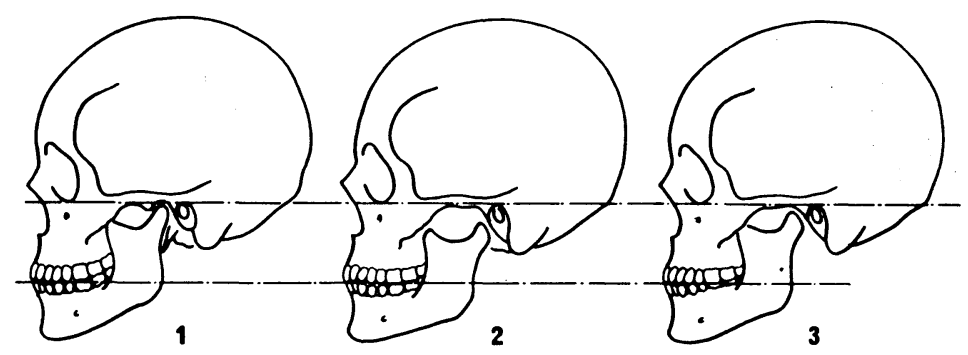

Fig.IV. Abnormal occlusion in Tozukayama. 1: normal occlusion, 2: reformed occlusion in Tozukayama. The mandibular condyle is dislocated postero-inferiorly, 3: additional (final) occlusion in Tozukayama. The condyle contacts with the mandibular fossa and the left lower cheek teeth were dislocated to the lingual side of the upper cheek teeth as shown in Fig. III-3.

横に連続するいわゆるクサビ状欠損と類似する磨耗が 見られる (Plate II-6,Figs. II, III-C)。乙の磨耗面 には近遠心方向の細かい条痕が認められる。島(1959) によると，歯ブラシなどで出来る磨耗は鋭い文字どお りのクサビ形面をなすが，古墳時代人の場合は断面は 鈍であり, ハシのような木片，あるいは竹棒を用いて 歯を清掃した結果であると考えられている。

本例の欠損むとれにあたると思われるが，下顎左側 のみに見られる点, また歯石の沈着が著しく，かつ，

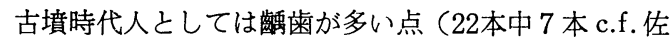
倉1963）などから見て, 口腔内の清掃が目的であった かどうかは疑問である。

\section{咬合状態}

正常な咬合状態 (Fig. I-1) では，下顎窩 (A)に下 顎頭関節面( a )が入り込んだ状態で上下顎歯列咬合面 全体（鋏状咬合の場合の前歯部は少々異なる）が接触 する (Fig. IV-1)。本例では, 上下顎歯列咬合面を接 触させると, 下顎頭は本来の下顎窩 (Fig. I-A) とで なく，拡大した関節面(B)と関節する (Fig. IV-2)。 つまり, 下顎頭が後下方にずれた位置で，一応の咬合 状態が得られていたと考えられる(Plate I-2)。なお, その状態では，前歯部は鉗子状の咬合となっており， 前歯部の咬耗から推測される本来の鋏状咬合とは異な っている点が注目される。

実は, 本例にはもう一つの副次的な咬合状態が見ら れる。すなわち, 左上下顎臼歯部の斜めの磨耗面が互 いに接触するようにして, 左下顎臼歯を左上顎臼歯の 舌側へ入り込ませると（Fig. III-3), 下顎頭が下顎 窩にはまり込んで, 本来の関節状態になる (Fig. IV3),ただし，その際に，前歯部では下顎歯が上顎歯の 舌側に入り込めないので，切歯を支点として下顎の後
方が上方やや右方へ動くような，通常とは逆の顎運動 が起こることになる。このような運動は生前にあ行な われていたと推察される。

\section{顎関節の変化}

$$
\text { 考察 }
$$

顎関節の後天的な異常は関節円板の炎症や損傷, あ るいは下顎枝の骨折などに起因することが多いとされ ている。しかし，本例では拡大した関節面む本来の関 節面とあまり変らないほどなめらかであり，関節窩で は両関節面の境界むはっきりしない。また，下顎枝 は左右と屯健全であり, 骨折の形跡は認められない (Plate I-3-5)。従って, 本例の顎関節は, 脱臼した 場所で本来の関節に代わって形成されたようないわゆ る新関節と考えるよりあ，何らかの原因で正常な関節 面が著しく拡大し，下顎頭が，下顎窩と拡大した関節 面とを往来することのできるような関節と考えた方が 無理がなさそうである。

なお，関節結節があまり発達していないのは (Fig. I- $C^{\prime}$ ), 下顎頭が後下方の関節面(B)にあるととが多 く，下顎窩(A)にある頻度が少なかったためか，ある いは逆に前方への移動を頻繁に行なったためとも推測 される。

咬合状態の変化

本例は，下顎頭が下顎窩の後下方に位置した状態で 一応の咬合状態 (Fig. IV-2) にあることとは前に述 べた。この状態での咬合面全体は耳眼水平面とほぼ平 行であり，正確な比較資料はないが，古墳時代の通常 の場合より臼歯部がやや下方に位置しているようであ る(Plate I-2)。

この咬合状態では，前述のように，前歯部は鉗子状 

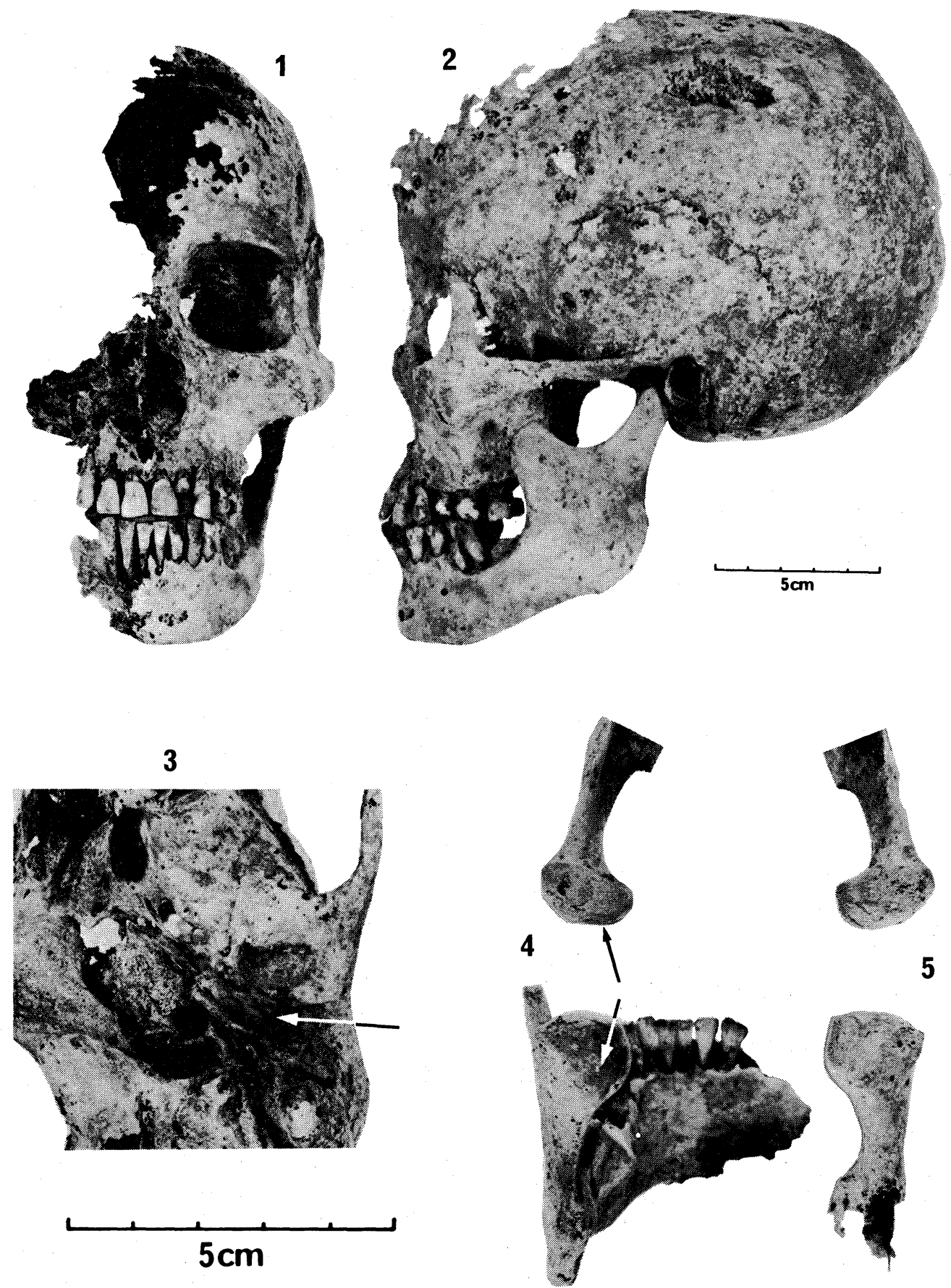

Plate I. 1.2: anterior and left lateral views of the skull, 3: expanded mandibular fossa, 4.5: superior and posterior views of the mandibular condyle. 

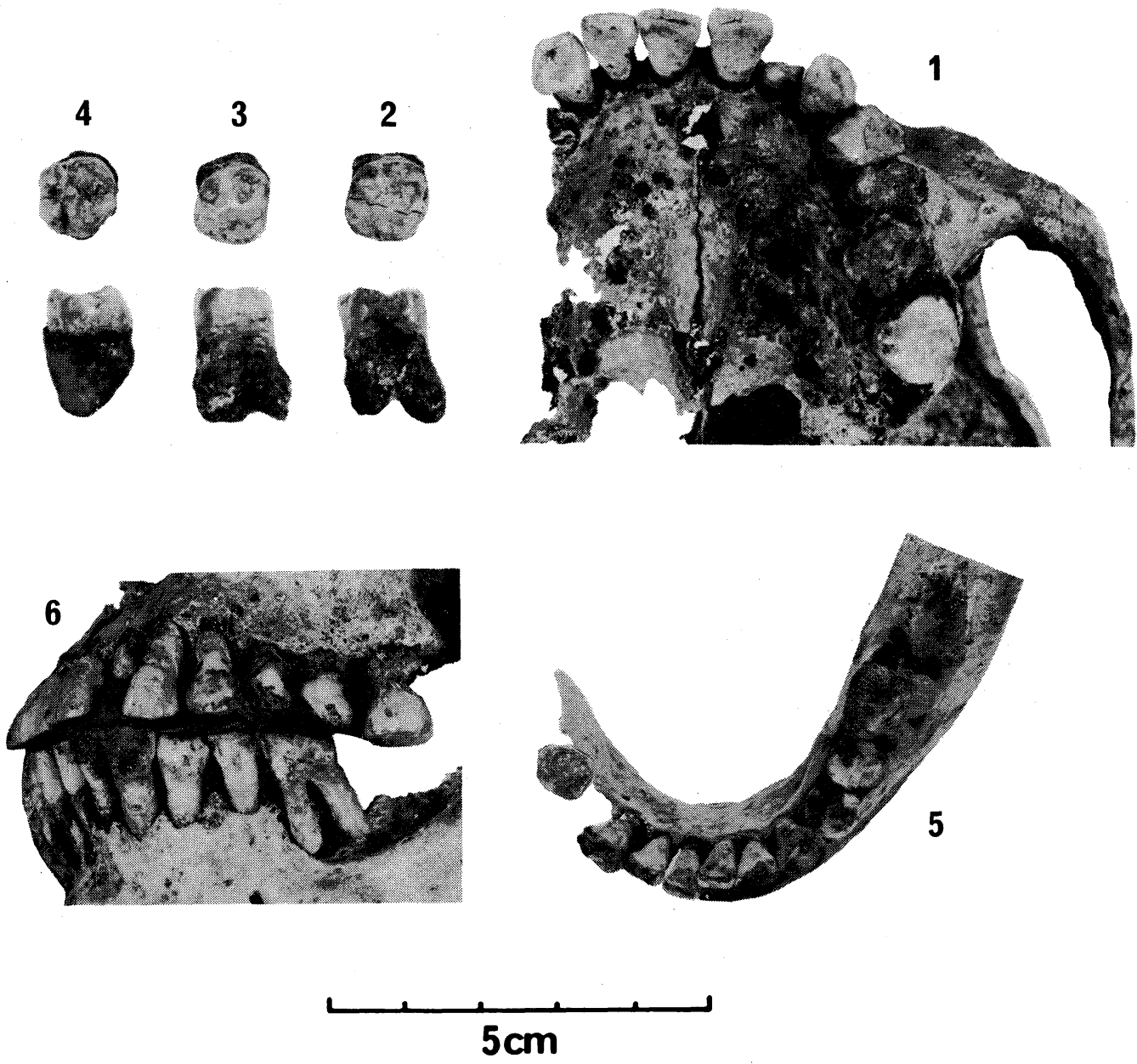

Plate II. 1: inferior view of the upper jaw, 2.3.4: occlusal and distal views of the 1st, 2nd and 3rd right upper cheek teeth, 5: superior view of the lower jaw, 6: lateral view of the left dental arches.

咬合になるので，鋏状咬合特有の上顎切歯舌側面と下 顎切歯唇側面との咬耗は起こらない。また，下顎頭が 後下方にずれた位置では, 下顎頭が前方へ移動して行 なわれる，いわゆる罒運動は困難と思われるので， 歯列咬合面に平行な咬耗はこの位置では起こりにくか っただろうと考えられる。従って正常な咬耗の大部分 は下顎頭の位置が正常な状態でなされた可能性が高 い。

これらのととと，歯が歯槽骨中を移動しやすい性質 とを考慮する亡, 本例での一応の咬合状態は, 萌出が 終了した後，ある期間が過ぎてから，それまで正常で あった下顎頭の位置に変化が起こり，とれが歯の移動
によって二次的に補正されて得られたものと推測され る。

すなわち, 下顎頭が後下方に移動すると, 日歯部咬 合面間に隙間が生じるが，上下顎歯が互いに接近する ことによりこの隙間が消失し，一応の咬合状態になっ たのであろう。なお，このような咬合状態では下顎頭 は下顎窩と関節しないが, ある程度以上開口した時 に，下顎頭が下顎窩に入り込んで関節していた可能性 はある。

歯の異常磨耗

左上下顎臼歯に斜めの異常な磨耗があるが, この磨 
耗面は横から (Fig. III-3 の矢印の方向) 見ると, 平 担ではなくかなり凹凸があり，上下顎歯の磨耗面が互 いに組み合うようになっている。ただし，完全に磨耗 面が接触するのではなく，数か所にやや不規則な紡錘 形の隙間がある。従って, との斜めの磨耗面自身が互 いにこすれ合っただけでなく，何か細い棒のような物 を介在していたてとあ多かったと推測される。

このととは, 臼歯歯冠部に小さな破損部分や咬合に よらない狭い磨耗部分が何か所むあることからも推察 される。つまり，比較的硬く細い物を斜め外下方から 内上方に，上下顎臼歯の間に挿入し (Fig-3 矢印), それを咬みながら，無理に動かすようなととをしたと 思われる。そして，第 2 象牙質の発達していることか ら，ての斜め異常磨耗は比較的長期間にゆっくりとな されたと考えられる。

実は，上下顎の歯列が完全な状態では，このよう に，左下顎臼歯が左上顎臼歯の舌側に入り込むような 運動は不可能である。従って, 左下顎臼歯の脱落した ことあ, 顎関節の変化とともに, この斜めの異常磨耗 の不可欠な原因と考えられる。

一方, クサビ状欠損は, 䫟関節の変化とは直接の関
係はないと思われる。ただし, 両方の磨耗を起とした と推測される棒状の物は別々な種類と考える必要はな いであろう。

\section{謝辞}

この人骨を研究する機会を与えて下さいました米沢 市教育委員会および関係の方々に深謝いたします。ま た，顎関節の異常につきご教示下さいました独協医科 大学口腔外科学朝倉昭人教授および耳鼻咽喉科学馬場 広太郎助教授, そして国立科学博物館人類学佐倉朔室 長に深謝いたします。

\section{引用文献}

馬場悠男, 茂原信生, 芹沢雅夫, 江藤盛治1983：戸塚 山古墳出土の人骨, 戸塚山第 137 号墳学術調査報告

書, 米沢市教育委員会 (印刷中)。

佐倉 朔 1963 : 日本人蘺歯率の時代的推移, 人類学 雑誌 $71: 153-177$ 。

島 五郎 1959 ：古墳時代人および石山石器時代人に 見た雨牙磨耗について，人類学雑誌 $67 ： 113-126$ 。 (1983年 3 月 5 日 受付) 


\title{
A Case of Abnormal Temporomandibular Joint and Dental Attrition in Protohistoric Female Skeleton from Tozukayama Mound in Yonezawa, Northern Japan
}

\author{
Hisao Baba, Nobuo Shigehara, \\ Masao Serisawa and Moriharu ETo \\ Department of Anatomy, \\ Dokkyo University School of \\ Medicine
}

In 1982, a female skeleton was excavated from protohistoric scallop-shaped (small square front with circular rear) mound. This skeleton generally shows typical characters as those from the same age (BABA et al., 1983). There, however, can be seen abnormal temporomandibular joint and dental attrition.

The articular surface of the mandibular fossa is extended postero-inferiorly onto the tympanic plate (Plate I, Fig. I-B). A corresponding facet is seen on the posterior surface of the mandibular condyle (Plate I, Fig. I-b).

Two kinds of abnormal attrition are seen as follows: first, oblique attrition on the lingual side of the upper cheek teeth and on the buccal side of the lower cheek teeth (Plate II-1,2, 6 , Figs. II, III-B); second, so-called wedge-shaped defect on the buccal side of the neck of the lower teeth (Plate II-6, Figs. II, III-C).

There are also two occlusal positions in this specimen. First is that the mandibular condyle is dislocated postero-inferiorly and the normal occlusal surfaces of the upper and lower teeth contact with each other (Figs. I-1,IV-2). Second is that the condyle fits with the original mandibular fossa and the surfaces by oblique attrition contact with each other (Figs. III-3, IV-3).

These two types of abnormal attrition were considered to be caused chiefly by a small chopstick-like object, and the oblique attrition had to be closely related with the abnormal expansion of the temporomandibular joint.

\section{馬 場 悠 男 独協医科大学第一解剖学教室 \\ 于321-02 栃木県下都賀郡壬生町北小林880 \\ Hisao BABA Department of Anatomy \\ Dokkyo University School of Medicine \\ Mibu, Tochigi 321-02 Japan}

